course. The profession, the university, and the community are all the better for his contributions. He will be sorely missed.

Bradley C. Canon

Vincent Davis

Karen Mingst

University of Kentucky

\section{Ralph Miliband}

Ralph Miliband, formerly Morris Hillquit Professor in the Department of Sociology at Brandeis and, later, Visiting Professor of Political Science at the CUNY Graduate Center in New York City, died in London on May 28. Miliband, born in Belgium and educated at the London School of Economics, was 70 . He was one of the foremost democratic socialist intellectuals of our time. He long stood as a central reference point for the Left of the British Labor movement and in the 1980s co-founded the Socialist Society to give political voice to critical groups on the political Left. He was also active in the British peace movement, opposition to the Vietnam War, and innumerable campaigns against social and political oppression, including in the exCommunist countries.

Miliband was a student of Harold Laski's at the London School of Economics after World War II. He began his teaching career at the LSE, where he stayed until 1969. His first book, Parliamentary Socialism (1961), was a magisterial argument about the processes and mechanisms whereby British Labour Party leaderships were ensnared by the workings of the British establishment. His polemic with Nicos Poulantzas about the nature of the capitalist state which began with a review of the latter's Political Power and Social Theory and continued for several years in different fora in the later 1960s, was central in the explosion of neoMarxist state theory that marked political sociology for at least a decade. Miliband, more than anyone else, was responsible for "bringing the state back" into political science and sociology. The State in Capitalist Society (1969), in which
Miliband combined a nearly Leninist vision of the workings of politics and the state in capitalist societies with a somewhat instrumentalist argument (strongly influenced by the work of his dear friend $C$. Wright Mills), drawing upon a wide range of comparative data to support this vision, is perhaps his bestknown work. Marxism and Politics, from the same period, is his most explicitly "strategic" work, seeking new wisdom from Marxism about the transcendence of advanced capitalism, clearly partook of "Eurocommunist" rethinking on the European Left. He published numerous other articles and several other books, including Capitalist Democracy in Britain, his most complete statement about British politics. Ralph Miliband was also the founding co-editor (in 1964, with John Saville) of The Socialist Register, an annual of Left reflections on theory and political developments that quickly won a central place in international Left debates. Like most Left scholars, he was moved to reflect on a number of basic questions about socialism in the light of the collapse of Sovietstyle regimes in the later 1980s. Unlike many, however, he concluded that a reformulation of arguments for socialist transformation was the task at hand. He was concluding a book presenting his case at the time of his death.

Miliband, who taught at Leeds University in England and York University in Canada, in addition to Brandeis, CUNY, and the LSE, was a striking and imposing public speaker, lecturer, and seminar leader. He combined a deep voice, rhetorical elegance, sense of humor and great charm with insistent urging toward sharp arguments and confrontations with the socialist tradition. He was able to combine these unique gifts with empathy and kindness. It was no accident that over decades, from his legendary seminar on "problems of contemporary socialism" (where the young guards of the British and North American New Lefts exchanged positions and ideas), his lectures on British politics and on Marxism at the LSE, to the many graduate seminars in state theory and the sociology of politics in the USA and Canada, he formed a devoted following of students. Miliband was a giving and successful mentor and colleague whose students around the world now form something of an "international" of their own.

Miliband's scholarly and political career are a rare model of commitment and success. The extent of his influence can be judged by the fact that in the mid-1970s he was very near the top of the APSA list of the most-cited political scientists, despite his own aversion for cultivating influence in such circles. All those who knew Ralph Miliband were inspired by his great gift for combining political and scholarly integrity with personal warmth and generosity. The same gifts made him a model companion for Marion Kozak and father for David and Edward. Those many people who counted on Ralph Miliband for support, intellectual sustenance, leadership, steadfastness and friendship, plus a wonderful, reassuring smile, have suffered a huge loss. So has critical scholarship in the social sciences.

George Ross

Brandeis University

\section{John Roche}

John Roche, 70, a former columnist and professor who also had served as a Capitol Hill staffer and presidential adviser, died May 6 at a hospital in Cambridge, Massachusetts, after a stroke. He lived in Weston, Massachusetts.

He had served as national chairman of the Americans for Democratic Action from 1962 to 1965 . He had been an ADA founder.

Beginning in the early $1960 \mathrm{~s}$, Dr. Roche wrote speeches for Sen. Hubert H. Humphrey (D-Minn.) and worked for Humphrey for a time after he became vice president in 1965. From 1966 to 1969 , Dr. Roche was an adviser to President Lyndon B. Johnson.

After that, he wrote a syndicated column, "A World Edgewise," for 14 years. He also had been a contributor to TV Guide's "News- 
watch" column. He had taught at Tufts University's Fletcher School of Law and Diplomacy in Medford, Mass., from 1973 until this year.

Dr. Roche, a native of Brooklyn, New York, served with the Army Air Force during World War II. A Phi Beta Kappa graduate of Hofstra College, he received a master's degree and a doctorate in political science from Cornell University.

He had served on the faculty of Haverford College from 1949 to 1956 and taught at Brandeis Uni- versity from 1956 to 1970 . At Brandeis, where he helped establish the government department, he was dean of the arts and sciences faculty from 1958 to 1961 .

Dr. Roche was an authority in the areas of political theory, constitutional law, and early American history. He wrote such books as The Quest for the Dream, Courts and Rights, Shadow and Substance, and Sentenced to Life.

He had been a trustee of the Smithsonian Institution's Woodrow
Wilson Center for Scholars. In the 1970s, he had served on the Presidential Commission on International Broadcasting and the U.S. Board for International Broadcasting.

Survivors include his wife of 47 years, Constance Ludwig Roche of Weston, a daughter, a brother and a granddaughter.

[Reprinted, with changes, from Washington Post, May 7, 1994]

\section{Moving? . . . . . Don't Forget to Notify APSA}

To ensure that all your subscriptions, membership information, and mailings reach you, return this form to APSA at least one month before you move.

Name:

Primary

Address:
Membership Number:

Secondary

Address (optional):

Date new address effective:

Please send all APSA correspondence to my primary address.

Please send the following checked correspondence to my secondary address, all other correspondence should be sent to my primary address.

口 Directory

口 Journals

Meeting Information

Renewals/General Information

Personnel Service Newsletter

Please return to: Membership Office

American Political Science Association

1527 New Hampshire Avenue, NW

Washington, DC 20036 